\title{
Truth Commissions
}


PENNSYLVANIA STUDIES IN HUMAN RIGHTS

Bert B. Lockwood, Jr., Series Editor 


\title{
Truth Commissions
}

Memory, Power, and Legitimacy

\section{Onur Bakiner}

\author{
$\overline{\text { PENN }}$ \\ UNIVERSITY OF PENNSYLVANIA PRESS \\ PHILADELPHIA
}


Copyright (C) 2016 University of Pennsylvania Press

All rights reserved. Except for brief quotations used for purposes of review or scholarly citation, none of this book may be reproduced in any form by any means without written permission from the publisher.

\author{
Published by \\ University of Pennsylvania Press \\ Philadelphia, Pennsylvania 19104-4112 \\ www.upenn.edu/pennpress \\ Printed in the United States of America \\ on acid-free paper
}

13579108642

Library of Congress Cataloging-in-Publication Data

Bakiner, Onur, author.

Truth commissions : memory, power, and legitimacy / Onur Bakiner.

pages $\mathrm{cm}$. - (Pennsylvania studies in human rights)

ISBN 978-0-8122-4762-6 (alk. paper)

1. Truth commissions-Political aspects-Case studies. 2. Political crimes and offenses-Investigation-Case studies. 3. Reconciliation-Political aspects-Case studies. 4. Memory-Political aspects-Case studies. I. Title. II. Series: Pennsylvania studies in human rights.

JC580.B35 2016

$323.4^{\prime} 9-\mathrm{dc} 23$ 